\title{
Fertility of crustal rocks during anatexis
}

\section{Journal Article}

Author(s):

Thompson, Alan Bruce

Publication date:

1996

Permanent link:

https://doi.org/10.3929/ethz-b-000423119

Rights / license:

In Copyright - Non-Commercial Use Permitted

Originally published in:

Transactions of the Royal Society of Edinburgh 87(1-2), https://doi.org/10.1017/S0263593300006428 


\title{
Fertility of crustal rocks during anatexis
}

\author{
Alan Bruce Thompson
}

\begin{abstract}
After many years of systematic experimental investigations, it is now possible to quantify the conditions for optimum fertility to melt production of most common crustal rock types as functions of temperature and $a_{\mathrm{H}_{2} \mathrm{O}}$, to about $30 \mathrm{kbar}$ pressure. Quartzo-feldspathic melting produces steady increases in melt proportion with increasing temperature. The exact melt fraction depends on the mineral mode relative to quartz-feldspar eutectics and the temperatures of mica dehydration melting reactions. Mica melting consumes $\mathrm{SiO}_{2}$ from residual quartz during the formation of refractory $\mathrm{Al}_{2} \mathrm{SiO}_{5}$, orthopyroxene, garnet or cordierite.

A simple graphical interpretation of experimental results allows a deduction of the proportions of mica and feldspar leading to optimum fertility. In effect, the mica dehydration melting reactions, at specific pressure and $a_{\mathrm{H}_{2} \mathrm{O}}$, are superimposed on quartz-feldspar melting relations projected onto $\mathrm{Ab}-\mathrm{An}-\mathrm{Or}$. Fertility to melt production varies with the mica to feldspar ratio and pressure. Pelites are more fertile than psammites at low pressures (e.g. $5 \mathrm{kbar}$ ), especially if they contain $\mathrm{An}_{40}$ to $\mathrm{An}_{50}$ plagioclase. At higher pressure (e.g. $10-20 \mathrm{kbar}$ ) and for rocks containing albitic plagioclase, psammites are more fertile than pelites. For a typical pelite (e.g. with $\mathrm{An}_{25}$ at $20 \mathrm{kbar}$ ), the cotectic with muscovite lies at higher $a_{\mathrm{H}_{2} \mathrm{O}}(\approx 0.6)$ and $X_{\mathrm{Ab}}(\approx 0.42)$ than with biotite $\left(a_{\mathrm{H}_{2} \mathrm{O}} \approx 0.35 ; X_{\mathrm{Ab}} \approx 0.32\right)$, thus dehydration melting of muscovite requires $10 \%$ more plagioclase for fertility than does biotite.

The first melts from dehydration melting of muscovite (with Plg + Qtz) are more sodic and form at lower temperatures than the first melts from Bio $+\mathrm{Plg}+\mathrm{Qtz}$. With increasing pressure, to at least $30 \mathrm{kbar}$, granite minimum and mica dehydration melts become more sodic. This indicates that $a_{\mathrm{H}_{2} \mathrm{O}}$ of such melts is greater than 0.3 .
\end{abstract}

KEY WORDS: optimum melt production, crustal anatexis, dehydration melting, metasediments, mica-feldspar ratio, pressure, $a_{\mathrm{H}_{2} \mathrm{O}}$.

Calculated pressure-temperature-time $(P-T-t)$ paths for continental collision (e.g. Thompson \& Connolly 1995) have shown that the attainment of temperatures in excess of $800^{\circ} \mathrm{C}$ within the continental crust requires unusual tectonic circumstances. Several experimental investigations have determined that at $10 \mathrm{kbar}(\approx 35 \mathrm{~km})$ the dehydration melting solidus (with albite and quartz) for muscovite is near $725^{\circ} \mathrm{C}$, and that for biotite is above $780^{\circ} \mathrm{C}$. Thus in continental collision orogens only small melt fractions are likely even in quartzo-feldspathic rocks, which represent the lowest temperature crustal anatexites. It is important to note here that studies using trace elements in mica and feldspar (e.g. Harris \& Inger 1992) to evaluate the degree of melting also suggest anatectic melt proportions of $10-15 \%$ to be responsible for some leucogranites.

Experiments on pelite (Vielzeuf \& Holloway 1988; Patiño Douce \& Johnston 1991) and psammite compositions (Vielzeuf \& Montel 1994; Patiño Douce \& Beard 1995) have provided modal and chemical information on minerals and quenched melts, when the latter exceeded $20 \%$. A few workers (LeBreton \& Thompson 1988; Skjerlie \& Johnston 1992, 1993; Gardien et al., 1995) have studied anatexis at low melt fractions. The principal experimental difficulty in obtaining compositions from small melt fractions arises because it is no trivial matter to analyse small regions of glass with an electron microprobe beam. Glass is easily partly vapourised and the chemistry from nearby or subsurface crystals is often included in the analysis. For future applications of petrological results to problems of crustal anatectic melt generation, it is important to obtain information on the distribution and ranges of composition of these small melt fractions.

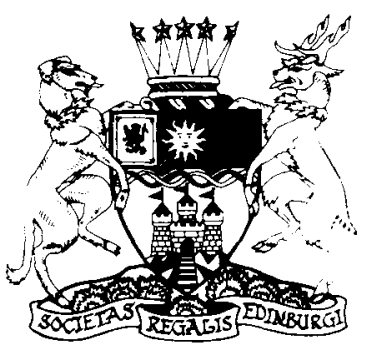

The purpose of this paper is to obtain such details from the available experimental studies at various degrees of melting and to suggest ways in which the interpretation of rocks and experimental charges may be developed to fully quantify the thermal and chemical evolution of anatectic melts.

\section{The problem of fertility (of crustal rocks to melt production)}

Melt production depends on the solidus temperature for a particular mineral assemblage and the modal proportions compared with the nearest eutectic. The first melts generated from a wide range of rock types [granitoid intrusive and felsic extrusive rocks, pelitic and psammite (including greywacke) metasedimentary rocks] have compositions close to the minimum/eutectic of quartz-feldspar (Qtz-Fsp) assemblages of the 'granite' system (Ab+Or+Qtz; Tuttle \& Bowen 1958; Luth et al. 1964; Huang \& Wyllie 1975; Winkler, summary from 1979).

Water greatly lowers the melting temperature of these minerals because of its high solubility in silicate melts at high pressure. The compositions of the granite minimum move away from Qtz towards Fsp with increasing $P_{\mathrm{H}_{2} \mathrm{O}}$. Therefore the fertility to melt production (where large melt fractions are generated over the smallest temperature intervals) in quartzofeldspathic rocks of different modes varies with depth in the continental crust.

The porosity of crystalline rocks in the middle and lower crust is so low that the amount of free $\mathrm{H}_{2} \mathrm{O}$ expected to be available for $\mathrm{H}_{2} \mathrm{O}$-saturated melting is very small-insufficient to produce more than a few per cent of minimum melt (Thompson \& Connolly 1995). The principal source for $\mathrm{H}_{2} \mathrm{O}$ 
is that stored in the crystal structures of micas and amphiboles. For the rock compositions of interest here we will concentrate on the fluid-absent (dehydration) melting of the two micas: muscovite and biotite. Even though Burnham (1967, 1979) has suggested that at the dehydration melting solidus for Mus + Plag + Qtz $\left(\approx 750^{\circ} \mathrm{C}, 10 \mathrm{kbar}\right)$ the $X_{\mathrm{w}}^{\mathrm{m}}$ is about $0 \cdot 6$, and at the Bio + Plag + Qtz solidus $\left(\approx 800-850^{\circ} \mathrm{C}\right.$ at $\left.10 \mathrm{kbar}\right)$ the $X_{\mathrm{w}}^{\mathrm{m}}$ is about $0 \cdot 35$, we do not know how $X_{\mathrm{w}}^{\mathrm{m}}$ relates to melt fraction. In any case, the fertility of rocks to crustal anatexis seems to be controlled very much by the proportion and composition of the micas and plagioclase undergoing melting with quartz. To simplify discussion, the symbol $X_{\mathrm{w}}^{\mathrm{m}}$ is used to denote the mole fraction of $\mathrm{H}_{2} \mathrm{O}$ in the melt and is considered equal to activity of $\mathrm{H}_{2} \mathrm{O}$ in the melt (Burnham 1979). The symbol $a_{\mathrm{H}_{2} \mathrm{O}}^{\text {fluid }}$ is used to denote water activity in the fluid and can be changed due to dilution by another component. The symbol $a_{\mathrm{H}_{2} \mathrm{O}}$ refers to water activity in the environment.]

Optimum fertility refers to a mineral mode (micas and feldspars present in eutectic proportion) that will produce the maximum amount of melt at, or just above, the solidus for the nearest eutectic. A 'fertile' composition which has the minerals of the eutectic reaction, but not in the eutectic proportion, will produce some melt at the dehydration melting solidus. Although precise modes can be deduced appropriate to rock fertility, for the purpose of the discussion in this paper pelites contain more mica than feldspar and quartz, whereas psammites contain more feldspar and quartz than mica. Much information about fertility to crustal anatexis is contained in experimental data on the change in composition and temperature of the 'granite' minimum, with increasing pressure and decreasing $a_{\mathrm{H}_{2} \mathrm{O}}$

\section{Change in composition of the haplogranite minimum and eutectic melt composition with pressure and $a_{\mathrm{H}_{2} \mathrm{O}}$}

In their pioneering experimental work, Tuttle and Bowen (1958) showed that the minimum in $\mathrm{Ab}+\mathrm{Or}+\mathrm{Qtz}$ at $\mathrm{H}_{2} \mathrm{O}$ saturation $\left(P_{\text {total }}=P_{\mathrm{H}_{2} \mathrm{O}}\right)$ migrated with increasing pressure towards $\mathrm{Ab}$ from 1 to $3 \mathrm{kbar}$. Subsequent high-pressure experiments demonstrated the dramatic increase in the feldspar to quartz ratio with increasing pressure (from about Fsp/ $\mathrm{Qtz} \approx 58 / 42$ at $1 \mathrm{~atm}$ to about $86 / 14$ at $30 \mathrm{kbar}$, wt $\%$ units shown in Fig. 1). The experiments of Luth et al. (1964) from 4 to 10 kbar (see also Luth 1976) and the estimates of Huang

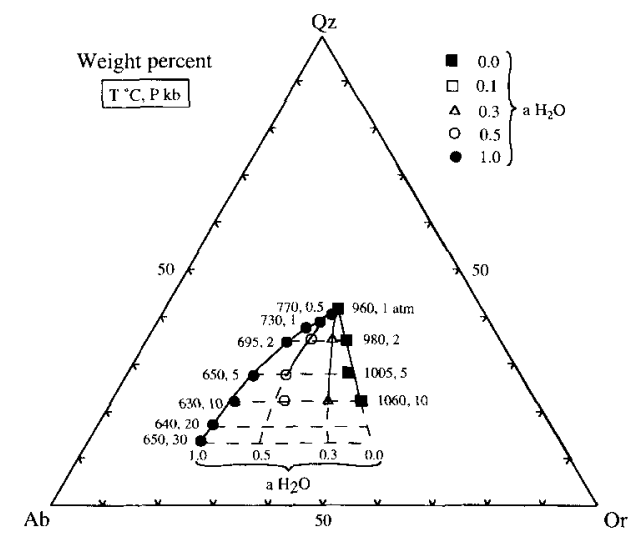

Figure 1 Minimum and eutectic compositions (wt $\%$ ) determined at various water activities in the system $\mathrm{Ab}+\mathrm{Or}+\mathrm{Qtz}+\mathrm{H}_{2} \mathrm{O}\left(+\mathrm{CO}_{2}\right)$. Modified from data summarised by Ebadi and Johannes (1991; figure 13: 293) with additional data for $\mathrm{H}_{2} \mathrm{O}$-saturated eutectics at 20 and $30 \mathrm{kbar}$ from Huang and Wyllie (1975). It is easily seen that the ratio $(\mathrm{Ab}+\mathrm{Or}) / \mathrm{Qtz}$ increases with pressure, apparently independently of $\mathrm{a}_{\mathrm{H}_{2}} \mathrm{O}$. and Wyllie (1975) at 20-30 kbar indicated that the migration of the minimum from 5 to $30 \mathrm{kbar}$ becomes more parallel to the $\mathrm{Ab}+\mathrm{Qtz}$ sideline. These results are shown in Figure 1, together with various more recent studies on the system $\mathrm{Ab}+\mathrm{Or}+\mathrm{Qtz}+\mathrm{H}_{2} \mathrm{O}+\mathrm{CO}_{2}$ (Holtz \& Johannes 1991; Ebadi \& Johannes 1991).

Some simplified statements about the migration of the minimum/eutectic in the $\mathrm{Ab}+\mathrm{Or}+\mathrm{Qtz}$ projection at various $a_{\mathrm{H}_{2} \mathrm{O}}$ may be made with these data. The $\mathrm{H}_{2} \mathrm{O}$ saturated minimum/eutectic $\left(a_{\mathrm{H}_{2} \mathrm{O}}=1\right)$ migrates, with increasing pressure, to much lower temperatures and towards $\mathrm{Ab}_{25}$, almost parallel to the $\mathrm{Ab}+\mathrm{Qtz}$ sideline, i.e. from $T=770^{\circ} \mathrm{C}, \mathrm{Ab}_{30} \mathrm{Or}_{3 \mathrm{i}}$ $\mathrm{Qtz}_{39} \mathrm{Wt} \%$ (500 bar $P_{\mathrm{H}_{2} \mathrm{O}}$, Tuttle \& Bowen 1958: 34) to $T=$ $650^{\circ} \mathrm{C}, \mathrm{Ab}_{67} \mathrm{Or}_{13} \mathrm{Qtz}_{20} \mathrm{wt} \%$ (30 kbar, Huang \& Wyllie 1975). The anhydrous minimum $\left(a_{\mathrm{H}_{2} \mathrm{O}}=0\right)$, migrates with increasing pressure to higher temperatures and towards $\mathrm{Ab}_{40} \mathrm{Or}_{60}$, almost parallel to the $\mathrm{Or}+\mathrm{Qtz}$ sideline, i.e. from $T=960^{\circ} \mathrm{C}$, $\mathrm{Ab}_{27} \mathrm{Or}_{32} \mathrm{Qtz}_{41}$ wt $\%$ (1 atm Schairer 1950; Bowen \& Tuttle 1958 ) to $T=1060^{\circ} \mathrm{C}, \mathrm{Ab}_{31} \mathrm{Or}_{48} \mathrm{Qtz}_{21} \mathrm{wt} \%$ (10 kbar, Ebadi \& Johannes 1991). For conditions of $a_{\mathrm{H}_{2} \mathrm{O}}<1$, the migration of the minimum/eutectic composition in the $\mathrm{Ab}+\mathrm{Or}+\mathrm{Qtz}$ projection is almost radial from the low pressure minima towards the $\mathrm{Ab}+\mathrm{Or}$ sideline.

An extremely important additional observation from Figure 1 is that irrespective of the $a_{\mathrm{H}_{2} \mathrm{O}}$ the minimum/eutectic occurs at approximately the same $\mathrm{Fsp} / \mathrm{Qtz}$ ratio at any particular pressure. The projected $X_{\text {or }}$ values corresponding to these shifts are shown in Figure $2 \mathrm{a}$, where it can be seen that $\mathrm{d} P / \mathrm{d} X_{\mathrm{Or}}$ changes from negative to positive between $a_{\mathrm{H}_{2} \mathrm{O}}=$ 0.5 and 0.3 . The changes in the $(\mathrm{Ab}+\mathrm{Or}) / \mathrm{Qtz}$ ratio of the minimum/eutectic composition in the $\mathrm{Ab}+\mathrm{Or}+\mathrm{Qtz}$ projection is shown as a function of temperature in Figure $2 b$. Here the compositional shifts with changing pressure and $a_{\mathrm{H}_{2} \mathrm{O}}$ can be compared with the compositions defining the 'thermal valley' at $P_{\mathrm{H}_{2} \mathrm{O}}=1 \mathrm{kbar}$ (Bowen \& Tuttle 1958, fig. 39). This simplified behaviour allows a straightforward thermodynamic treatment of the migration of the minimum temperature and composition with both pressure and $a_{\mathrm{H}_{2} \mathrm{O}}$, within a relatively small triangular volume of $\mathrm{Ab}+\mathrm{Or}+\mathrm{Qtz}+a_{\mathrm{H}_{2} \mathrm{O}}$ composition space.

\section{Micas and haplogranites $\left(\mathrm{Ab}+\mathrm{Or}+\mathrm{Qtz}+\mathrm{H}_{2} \mathrm{O}\right)$ at various $\boldsymbol{a}_{\mathrm{H}_{2} \mathrm{O}}$}

There have been several experimental studies during the last decade in the $\mathrm{H}_{2} \mathrm{O}$ undersaturated region of the system $\mathrm{NaAlSi}{ }_{3} \mathrm{O}_{8}(\mathrm{Ab})+\mathrm{KAlSi}_{3} \mathrm{O}_{8}(\mathrm{Or})+\mathrm{SiO}_{2}(\mathrm{Qtz})+\mathrm{H}_{2} \mathrm{O}+$ diluting components. The compositions of coexisting phases as functions of $P, T$, and $a_{\mathrm{H}_{2} \mathrm{O}}$ are vital in understanding the dehydration melting reactions of micas.

\subsection{Distinct $\boldsymbol{P}-\boldsymbol{T}$ regions for minima and eutectica in $\mathrm{Ab}+\mathrm{Or}+\mathrm{Qtz}+\mathrm{H}_{2} \mathrm{O}$ at various values of $\boldsymbol{a}_{\mathrm{H}_{2} \mathrm{O}}$}

Luth et al. (1964) concluded that at $\mathrm{H}_{2} \mathrm{O}$-saturation the fourcomponent system $\mathrm{Ab}+\mathrm{Or}+\mathrm{Qtz}+\mathrm{H}_{2} \mathrm{O}$ changed from minimum to eutectic melting at pressures above about $3.6 \mathrm{kbar}$. By including information on the pressure dependence of the alkali feldspar critical temperature, the interpretation of Stewart \& Roseboom (1962) would displace this intersection to lower than $3 \mathrm{kbar} P_{\mathrm{H}_{2} \mathrm{O}}$. The $P-T$ of the critical curve, presented by Waldbaum and Thompson (1969), allowed revision of this intersection point to about $2.5 \mathrm{kbar}$. The projection of the $P-T$ of the alkali feldspar critical curve (AFC) into $\mathrm{Ab}+\mathrm{Or}+\mathrm{Qtz}$ phase relations, under anhydrous and $\mathrm{H}_{2} \mathrm{O}$ saturation conditions, was shown by Huang and Wyllie (1975).

It is now possible to separate in $P-T$ space a region of $\mathrm{Ab}+\mathrm{Or}+\mathrm{Qtz}+\mathrm{H}_{2} \mathrm{O}$ minima at higher temperatures than the critical curve from eutectic behaviour at lower temperatures 

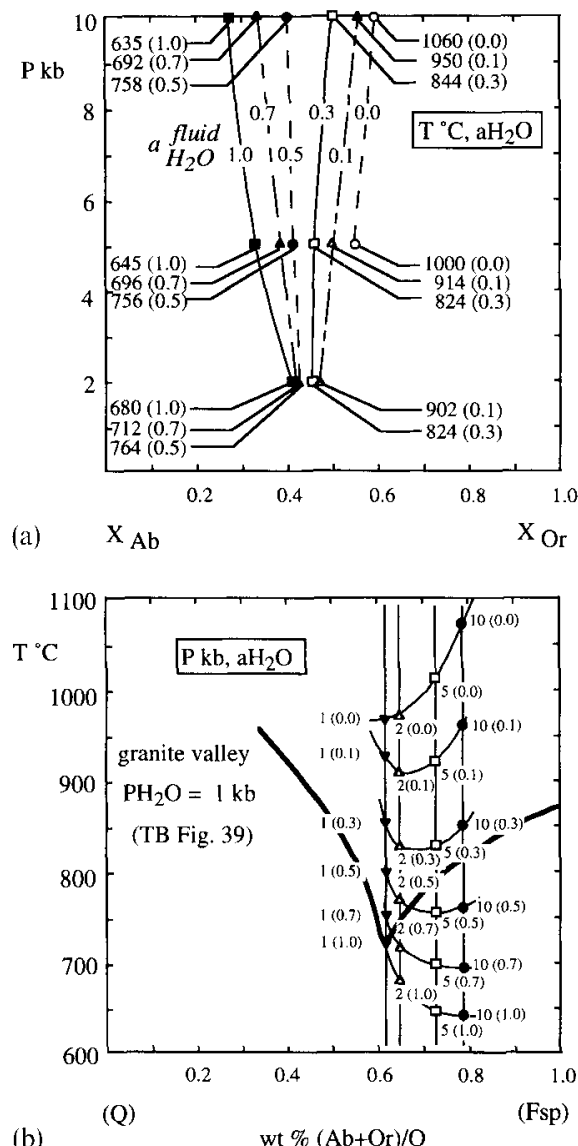

(b)

Figure 2 Projection of $\mathrm{Ab}+\mathrm{Or}+\mathrm{Qtz}+\mathrm{H}_{2} \mathrm{O}$ minimum/eutectic as a function of pressure (kbar), temperature $\left({ }^{\circ} \mathrm{C}\right)$ and $a_{\mathrm{H}_{2} \mathrm{O}}$ in $\mathrm{H}_{2} \mathrm{O}+\mathrm{CO}_{2}$ fluids. (a) Projected onto $\mathrm{Ab}+\mathrm{Or}$ join $\left(X_{\mathrm{Or}}, \mathrm{mol} \%\right.$ ) plotted from data in table 2 of Ebadi and Johannes (1991: 289). The change in slope of $\mathrm{d} P / \mathrm{d} X_{\mathrm{Or}}$ occurs between $a_{\mathrm{H}_{2} \mathrm{O}}=0 \cdot 3-0 \cdot 5$. (b) Projected as the ratio $(\mathrm{Ab}+\mathrm{Or}) / \mathrm{Q}(\mathrm{wt} \%)$ using data from Ebadi and Johannes (1991; table 2; fig. 13), Luth et al. (1964) and Tuttle and Bowen (1958). The liquidus surface for $\mathrm{Ab}_{50} \mathrm{Or}_{50}$ for $P_{\mathrm{H}_{2} \mathrm{O}}=1 \mathrm{kbar}$ (granite valley) is shown from Tuttle and Bowen (1958, fig. 39).

(also at quartz/saturation). The ternary minimum in $\mathrm{Ab}+\mathrm{Or}+\mathrm{Qtz}$ lies at a lower temperature than the binary $\mathrm{Ab}+\mathrm{Or}$ minimum at any particular $a_{\mathrm{H}_{2} \mathrm{O}}^{\text {flu }}$. Thus the critical curve at quartz saturation, separating minimum from eutectic conditions in haplogranites, will lie some degrees lower than illustrated for the AFC here. In Figure 3, the position of the AFC in $P-T$ space is compared with the $\mathrm{Ab}+\mathrm{Or}+\mathrm{Qtz}+\mathrm{H}_{2} \mathrm{O}$ solidus at various $a_{\mathrm{H}_{2} \mathrm{O}}^{\text {flu }}$ using the experimental results of Keppler (1989) and Ebadi \& Johannes (1991). As can be seen in Figure 3, the $P-T$ region inferred for the formation of many granulites and for crustal anatexis (e.g. at $10 \mathrm{kbar}$ at temperatures greater than $800^{\circ} \mathrm{C}$ ) lie in the minimum region, not the eutectic region.

The important geological consequence of melting at a haplogranite minimum is that the melting temperature and anatectic melt composition, for any particular pressure and $a_{\mathrm{H}_{2} \mathrm{O}}$, are determined by the bulk composition (particularly the $\mathrm{Ab} / \mathrm{Or}$ ratio, Fig. 2). Conversely, at eutectica the initial melt composition and temperature are independent of the phase proportions. It remains to be investigated whether natural rock compositions will exhibit $\mathrm{Ab} / \mathrm{Or}$ minima as opposed to eutectica, when the potassic feldspar in any rock is completely substituted by muscovite or biotite.

\subsection{Dehydration melting of mica relative to the haplogranite system}

Micas in lower crustal rocks are important sources of $\mathrm{H}_{2} \mathrm{O}$ for anatexis. In rocks that contain mica, feldspar and quartz,

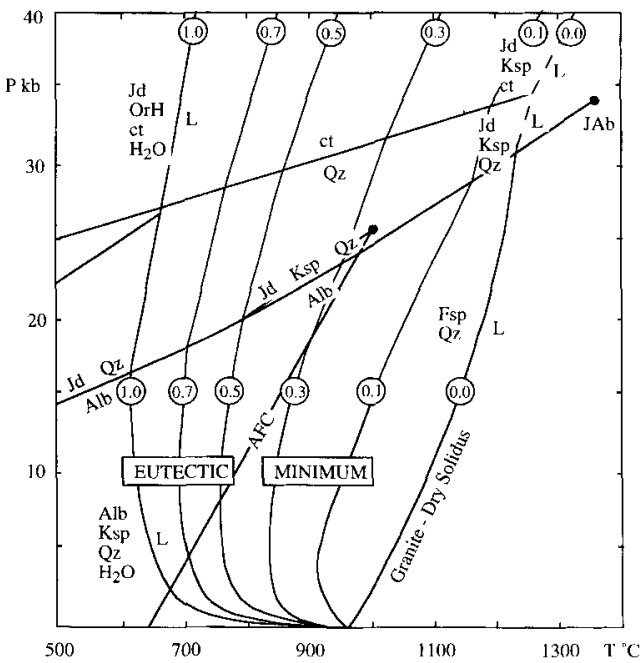

Figure 3 Minima and eutectic regions in $\mathrm{Ab}+\mathrm{Or}+\mathrm{Qtz}$ at various

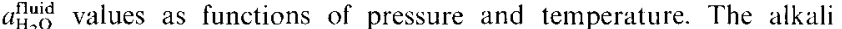
feldspar $(\mathrm{Ab}+\mathrm{Or})$ critical curve $(\mathrm{AFC})$ from Waldbaum and Thompson (1969) lies between anhydrous (dry granite) and $\mathrm{H}_{2} \mathrm{O}$ saturated solidi (Luth et al. 1964, Huang \& Wyllie 1975). The extrapolation into the $\mathrm{H}_{2} \mathrm{O}$ undersaturated region is possible using the experimental results on $\mathrm{Ab}+\mathrm{Or}+\mathrm{Qtz}+\mathrm{H}_{2} \mathrm{O}+\mathrm{CO}_{2}$ (to $10 \mathrm{kbar}$, Ebadi \& Johannes 1991) and 15 kbar (Keppler 1989). The AFC separates higher temperature lower $a_{\mathrm{H}, \mathrm{O}}^{\text {fluid }}(\mathrm{Ab}+\mathrm{Or}+\mathrm{Qtz})$ minima from lower temperature higher $a_{\mathrm{H}_{2} \mathrm{O}}^{\text {fluid }}$ eutectica. The broken lines show extrapolations to higher pressures within the stability of feldspar, within the stability ficid of jadeite plus alkali feldspar (or orthoclase hydrate, $\mathrm{Or} \mathrm{H}$, $\mathrm{KAlSi}_{3} \mathrm{O}_{8} \cdot \mathrm{H}_{2} \mathrm{O}$; Huang \& Wyllie 1975), plus coesite.

but without excess $\mathrm{H}_{2} \mathrm{O}$, fluid-absent (dehydration) melting occurs at temperatures higher than appropriate $\mathrm{H}_{2} \mathrm{O}$-saturated solidi. In the $P-T$ diagram of Figure 4 , the dehydration melting of muscovite granite (Huang \& Wyllie 1981), of Mus + Ab+Qtz (Petö \& Thompson 1974; Petö 1976) and the dehydration melting interval for Bio + Plag + Qtz (LeBreton \& Thompson 1988; Vielzeuf \& Holloway 1988) are shown relative to the haplogranite melting results of Figure 3 and the alkali feldspar critical curve (AFC).

Important for our purposes from Figure 4 is that muscovite dehydration melting (with albite and quartz) occurs at lower temperatures than the AFC, whereas biotite dehydration melting (with plagioclase and quartz) occurs at higher temperatures than the AFC. We will next consider melting reactions with binary $\mathrm{K}-\mathrm{Na}$ feldspars, i.e. mica instead of $\mathrm{K}$-feldspar and albite as plagioclase.

\subsection{Differences in dehydration melting of muscovite- bearing compared with biotite-bearing assemblages}

In mica dehydration melting the amount of melt produced is determined by the proportions of mica to feldspar, relative to the composition of the minimum or eutectic between them, as well as the width of the melting interval caused by crystalline solutions (e.g. see Burnham 1967, 1979; Thompson 1982, 1988). Muscovite and biotite require excess $\mathrm{Al}_{2} \mathrm{O}_{3}, \mathrm{MgO}$ (and $\mathrm{FeO}$ ) above the feldspar composition as well as $\mathrm{H}_{2} \mathrm{O}$ to form from their equivalent anhydrous assemblages. It was suggested by Burnham (1979) that initial muscovite dehydration melting corresponds to an $X_{\mathrm{w}}^{\mathbf{m}}$ of about 0.6 and initial biotite dehydration melting to about $0 \cdot 35$. The observations of LeBreton and Thompson (1988, fig. 4) suggest that, depending on the biotite composition, $X_{\mathrm{w}}^{\mathrm{m}}$ may vary. For example, more Fe-rich biotite may begin dehydration melting at $780^{\circ} \mathrm{C}, X_{\mathrm{w}}^{\mathrm{m}}=$ 0.5 and extend to $800^{\circ} \mathrm{C}, X_{\mathrm{w}}^{\mathrm{m}}=0.4$ for more $\mathrm{Mg}, \mathrm{F}$ or Ti richer compositions, and thus further into the projected 'minimum' regions.

Because muscovite dehydration melting for pelites and 

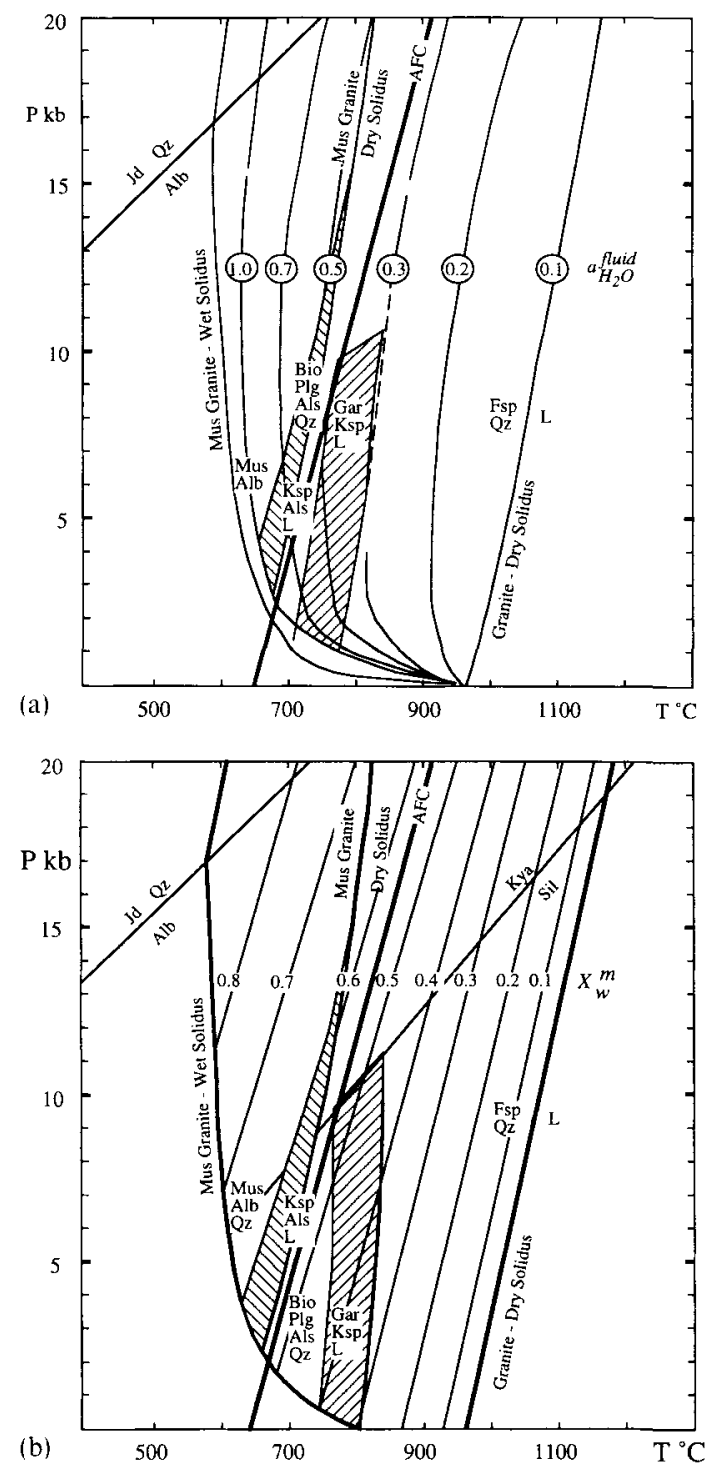

Figure $4 P-T$ diagram showing the $\mathrm{H}_{2} \mathrm{O}$ saturated (wet) and dehydration melting (dry) solidi for a muscovite granite (Huang \& Wyllie 1981) with dehydration melting of muscovite- and biotitebearing quartzo-feldspathic assemblages relative to haplogranite melting and the AFC (from Fig. 3). The reaction Mus+ Alb+ $\mathrm{Qtz} \rightarrow \mathrm{Ksp}+$ Als $+\mathrm{L}$ (broken line, Petö \& Thompson 1974; Petö 1976) is taken to mark the lower $T$ limit of plagioclase reactions (see Thompson \& Tracy 1979). The interval for the reaction Bio+ $\mathrm{Plag}+\mathrm{Als}+\mathrm{Qtz} \rightarrow \mathrm{Gar}+\mathrm{Ksp}+\mathrm{L}$ begins at about $790^{\circ} \mathrm{C}$ at $10 \mathrm{kbar}$ (dotted line. LeBreton \& Thompson 1988) and ends at about $860^{\circ} \mathrm{C}$ (Vielzeuf \& Holloway 1986). The dehydration melting of muscovite lies at lower temperatures than $\mathrm{AFC}$ - that is, within the region of $\mathrm{Ab}+\mathrm{Or}+\mathrm{Qtz}$ eutectica, whereas the dehydration melting of biotite lies within the region of $\mathrm{Ab}+\mathrm{Or}+\mathrm{Qtz}$ minima. (a) Contoured for $a_{\mathrm{H}_{2} \mathrm{O}}^{\text {fluid }}$ from Fig. 3; ( b) contoured for $X_{\mathrm{w}}^{\mathrm{m}}$ obtained by Thompson (1988) using the methods of Burnham (1979).

granites lies on the low-temperature (two-phase) side of the $\mathrm{AFC}$, the melting of Mus $+\mathrm{Alb}+\mathrm{Qtz}$ will be eutectic. The eutectic will occur over a narrow temperature interval $\left(<20^{\circ} \mathrm{C}\right)$ as muscovite does not show extensive solid solution (compared with biotite). Thus the melting of common natural proportions of muscovite and albite will generate quartz-saturated solidi very close in temperature to one another and obviously melts of the same composition.

The dehydration melting interval of Bio + Plag + Qtz is spread out by more than $100^{\circ} \mathrm{C}$ because of biotite crystalline solution (mainly $\mathrm{Fe}-\mathrm{Mg}$, but involving $\mathrm{Al}_{2} \mathrm{O}_{3}, \mathrm{TiO}_{2}$ and $\mathrm{F}$ in many instances). Furthermore, the extent of biotite dehydration melting appears to be strongly controlled by the coexisting plagioclase composition as well as by its amount. According to the picture revealed in Figure 4, dehydration melting of $\mathrm{Bio}+\mathrm{Plag}+\mathrm{Qtz}$ will be related to minima and not the eutectic region of $\mathrm{Ab}+\mathrm{Or}+\mathrm{Qtz}+\mathrm{H}_{2} \mathrm{O}$ (projected to lowered $a_{\mathrm{H}_{2} \mathrm{O}}$ ). In this instance, dehydration melting of biotite in specific assemblages will begin at very different temperatures depending on $X_{\text {Or }}$ in albite, $\mathrm{Fe} / \mathrm{Mg}$ in biotite and the proportions of these minerals to one another. This explains why there is considerably more variability in the solidus temperatures and melt compositions for biotite dehydration melting (LeBreton \& Thompson 1988; Vielzeuf \& Holloway 1988; Patiño Douce \& Johnston, 1991; Vielzeuf \& Montel 1994; Gardien et al. 1994) compared with muscovite dehydration melting. These features also partly explain why there are also greater differences in melt amount from biotite dehydration melting experiments compared with muscovite dehydration melting experiments (Skjerle \& Johnston 1992, 1993; Gardien et al. 1995). These aspects will be considered further in the discussion of the effect of natural rock compositions on fertility.

Until now we have mainly been concerned with the significance of feldspar composition, or projected $X_{\mathrm{Or}}$ ratio at $\mathrm{SiO}_{2}$ saturation, for the phase relations relevant to understanding crustal anatexis. A further fact to be considered is that the amount of quartz relative to mica exerts strong controls on the types of melting reactions and the width of melting temperature intervals because of the nature of the residual minerals.

\section{Dehydration melting reactions and residual mineralogy}

Both micas melt incongruently to give $\mathrm{H}_{2} \mathrm{O}$ undersaturated liquids that are richer in $\mathrm{H}_{2} \mathrm{O}$ than the micas themselves. The dehydration melting of muscovite releases $\mathrm{KAISi}_{3} \mathrm{O}_{8}$ and $\mathrm{H}_{2} \mathrm{O}$ to the melt, but consumes one mole of $\mathrm{SiO}_{2}$ from the rock to form residual $\mathrm{Al}_{2} \mathrm{SiO}_{5}$ (often sillimanite), according to the simplified reaction

$$
\mathrm{KAl}_{3} \mathrm{Si}_{3} \mathrm{O}_{10}(\mathrm{OH})_{2}+\mathrm{SiO}_{2}=\mathrm{KAlSi}_{3} \mathrm{O}_{8}+\mathrm{Al}_{2} \mathrm{SiO}_{5}+\mathrm{H}_{2} \mathrm{O}
$$

The dehydration melting behaviour of phlogopite is analogous, but consumes three moles of $\mathrm{SiO}_{2}$ during the formation of residual enstatite according to

$$
\mathrm{KMg}_{3} \mathrm{AlSi}_{3} \mathrm{O}_{10}(\mathrm{OH})_{2}+3 \mathrm{SiO}_{2}=\mathrm{KAlSi}_{3} \mathrm{O}_{8}+3 \mathrm{MgSiO}_{3}+\mathrm{H}_{2} \mathrm{O}
$$

Because both micas exhibit the Tschermak's exchange $\left(\mathrm{Al}_{2} \mathrm{Mg}{ }_{-1} \mathrm{Si}_{-1}\right)$, garnet or cordierite or other $\mathrm{MgO}+\mathrm{Al}_{2} \mathrm{O}_{3}$ minerals are also commonly produced as residual phases.

An important question is by how much is the Fsp/Qtz ratio decreased to generate the minimum/eutectic composition when coexisting with $\mathrm{SiO}_{2}$-bearing residual minerals, for rocks that contain mica instead of $\mathrm{KAlSi}_{3} \mathrm{O}_{8}$ ? Calculations were performed relative to the estimated $\mathrm{Ab}+\mathrm{Or}+\mathrm{Qtz}$ minimum compositions (Fig. 1) for $a_{\mathrm{H}_{2} \mathrm{O}}=0 \cdot 6$ and $0 \cdot 35$, corresponding to the approximate respective conditions for muscovite and biotite dehydration melting. The recalculated minimum compositions in Table 1 represent the proportions of plagioclase and mica required to produce a sillimanite-, or enstatitebearing residue coexisting with the granite minimum melt compositions. These displacements of the $\mathrm{Ab}+\mathrm{Or}+\mathrm{Qtz}$ minimum compositions, presented in Figure 5 for pressures to $30 \mathrm{kbar}$ and $a_{\mathrm{H}_{2} \mathrm{O}}=0.6$ and 0.35 , are clear indicators that different fertilities are expected when mica dehydration melting produces refractory residual minerals. Very different chemical trends in granite evolution are to be expected because of the 
Table 1 Calculation of the amount of quartz required relative to the granite minimum compositions when muscovite and biotite consume quartz during the formation of the residual minerals $\mathrm{Al}_{2} \mathrm{SiO}_{5}$ and $\mathrm{MgSiO}_{3}(\mathrm{Fig} .5$, wt $\%)$. Reaction $(1)$ : $\mathrm{Mus}(398)+\mathrm{Qtz}(60)=\mathrm{Ksp}(278)+\mathrm{Al}_{2} \mathrm{SiO} \mathrm{O}_{5}$ $(162)+\mathrm{H}_{2} \mathrm{O}(18)$. Reaction (2): Phl (417) $+3 \mathrm{Qtz}(180)=\mathrm{Ksp}(278)+3 \mathrm{MgSiO}_{3}(301)+\mathrm{H}_{2} \mathrm{O}(18)$.

\begin{tabular}{|c|c|c|c|c|c|c|c|c|c|c|}
\hline & \multicolumn{5}{|c|}{ Pressure (kbar) for $a_{\mathrm{H}_{2} \mathrm{O}}=0.6$} & \multicolumn{5}{|c|}{ Pressure (kbar) for $a_{\mathrm{H}_{2} \mathrm{O}}=0.35$} \\
\hline & 2 & 5 & 10 & 20 & 30 & 2 & 5 & 10 & 20 & 30 \\
\hline \multicolumn{11}{|c|}{ (a) Granite minimum composition (wt $\%$ ) } \\
\hline Qtz & 35 & 28 & 23 & 18 & 13 & 35 & 28 & 23 & 18 & 13 \\
\hline $\mathrm{Ab}$ & 29 & 28 & 28 & 29 & 30 & 33 & 36 & 38 & 40 & 42 \\
\hline Or & 36 & 44 & 49 & 53 & 57 & 32 & 36 & 39 & 42 & 45 \\
\hline $\mathrm{Ab}$ & $35^{*}$ & $44^{*}$ & $49^{*}$ & $53^{*}$ & $57^{*}$ & $32 \dagger$ & $36 t$ & $39 \div$ & $42 \dagger$ & $45 t$ \\
\hline Mus & $41^{*}$ & $40^{*}$ & $40^{*}$ & $41^{*}$ & $43^{*}$ & - & - & - & - & - \\
\hline Qtz' & $41^{*}$ & $34^{*}$ & $29 *$ & $24 *$ & $19 \cdot 5 *$ & $56 \cdot 4 \dagger$ & $51 \cdot 3 \dagger$ & $47.6+$ & $44 \uparrow$ & $40.2+$ \\
\hline $\mathrm{H}_{2} \mathrm{O}$ & $1.87 *$ & $1.81 *$ & $1.81^{*}$ & $1.88 *$ & $1 \cdot 94 *$ & $2 \cdot 13 \dagger$ & $2 \cdot 33+$ & $2 \cdot 4 \dagger$ & $2.6 t$ & $2 \cdot 7 \dagger$ \\
\hline Sil & $16.9 *$ & $163^{*}$ & $16 \cdot 3 *$ & $16.9 *$ & $17 \cdot 5^{*}$ & - & - & - & - & - \\
\hline Bio & - & - & - & - & - & $49+$ & $54 t$ & $57+$ & $60^{\dagger}$ & $63 t$ \\
\hline Ens & - & - & - & - & - & $36 t$ & $39 \div$ & $41 \dagger$ & $43 \dagger$ & $45 \cdot 5 \dagger$ \\
\hline \multicolumn{11}{|c|}{$\begin{array}{l}\text { Equivalent granite minimum compositions } \\
\text { [Qtz' from (b): } A b+O r \text { from (a) wt } \% \text { ) }\end{array}$} \\
\hline Qtz' & 39 & 32 & 28 & 23 & 19 & $46 \cdot 5$ & 42 & 38 & 35 & 32 \\
\hline $\mathrm{Ab}$ & 27 & 41 & 46 & 50 & 53 & $26 \cdot 3$ & 29 & 31 & 33 & 35 \\
\hline Or & 34 & 27 & 26 & 27 & 28 & $27 \cdot 2$ & 29 & 31 & 32 & 33 \\
\hline
\end{tabular}

*Using reaction (1).

+ Using reaction (2).

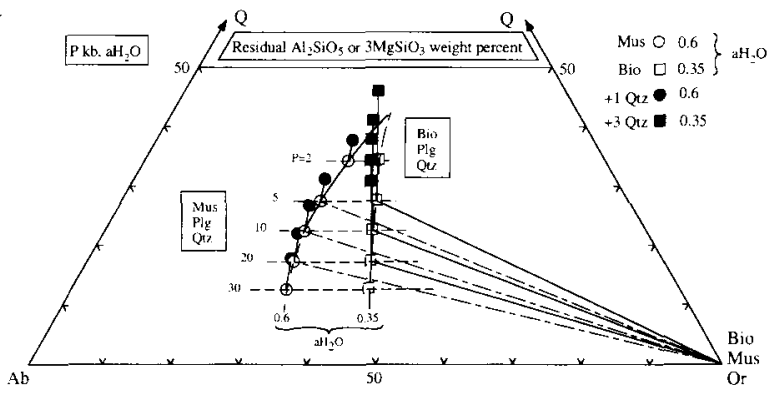

Figure 5 Compositional displacements $(w t \%)$ of $\mathrm{Ab}+\mathrm{Or}+\mathrm{Qtz}$ minima due to the consumption of quartz through the formation of residual minerals (one $\mathrm{Al}_{2} \mathrm{SiO}_{5}$ and three $\mathrm{MgSiO}_{3}$ ). The closed symbols show the displacements of the modal mineralogy (mica, plagioclase, quartz) that correspond to the eutectica/minima in $\mathrm{Ab}+\mathrm{Or}+\mathrm{Qtz}$ (open symbols) for values of $a_{\mathrm{H}_{2} \mathrm{O}}=0.6$ and 0.35 , appropriate to muscovite (circles) and biotite (squares) dehydration melting, respectively from Table 1.

subsequent mineralogical behaviour resulting from the separation of melt from its silica-enriched refractory residue.

\section{5. $\mathrm{SiO}_{2}$ content of anatectic melts and residual mineralogy}

Two apparently opposing effects which change the $\mathrm{SiO}_{2}$ content are at work during crustal anatexis. The composition of the granite minimum in $\mathrm{Ab}+\mathrm{Or}+\mathrm{Qtz}$ migrates uniformly away from quartz and towards the feldspar sideline with increasing pressure (Fig. 1). Thus quartz-poor compositions, e.g. syenites, would be fertile to anatexis at high pressures, whereas granites with lower Fsp/Qtz ratios would be fertile at lower pressures (Huang \& Wyllie 1975). The preliminary experimental data suggest that the value of the ratio $(\mathrm{Ab}+\mathrm{Or}) / \mathrm{Q}$ is independent of $a_{\mathrm{H}_{2} \mathrm{O}}$ at any particular pressure (Fig. 2), but is a strong function of temperature (Fig. 1). Thus the modal mineralogy (i.e. the Fsp/Qtz ratio) of felsic intrusives is a crude barometer that applies regardless of differences in $a_{\mathrm{H}_{2} \mathrm{O}}$ or cooling histories.

On the other hand, the formation of residual minerals (e.g. sillimanite, enstatite, garnet or cordierite) during mica dehydration melting depletes the bulk composition in $\mathrm{SiO}_{2}$. Thus the overall result of underestimating the initial quartz content after considering mica dehydration melting, gives higher interpreted modal Fsp/Qtz ratios, which in turn would lead to overestimates of intrusion depth (pressure). The graph in Figure 5 can be used to assess the quartz contents necessary for optimum fertility in mica-bearing rocks compared with the effect of pressure on the Fsp/Qtz ratio of the haplogranite minimum.

\section{Melt evolution of ternary feldspars with quartz at various $\mathrm{H}_{2} \mathrm{O}$ activities}

The crystal liquid equilibrium of crustal magmas is controlled by a delicate interplay of mafic and felsic components. However, the ternary feldspar system An $\left(\mathrm{CaAl}_{2} \mathrm{Si}_{2} \mathrm{O}_{8}\right)+\mathrm{Ab}$ $\left(\mathrm{NaAlSi}_{3} \mathrm{O}_{8}\right)+\mathrm{Or}\left(\mathrm{KAlSi}_{3} \mathrm{O}_{8}\right)$ at quartz saturation provides a subset of constraints on the evolution of crustal melts. Several sets of experimental data on the phase relations of coexisting plagioclase, alkali feldspar and melt coexisting with quartz at $\mathrm{H}_{2} \mathrm{O}$ saturation will be examined first to give important information on the temperature, pressure and $a_{\mathrm{H}_{2} \mathrm{O}}$ conditions for the anatexis of quartzo-feldspathic rocks and the fractional crystallisation of more mafic magmas.

\subsection{The five-phase (Plag, Ksp, Qtz, L, $\mathrm{H}_{2} \mathrm{O}$ ) equilibrium at $a_{\mathrm{H}_{2} \mathrm{O}}=1$ with increasing pressure}

The $\mathrm{H}_{2} \mathrm{O}$ and quartz saturated eutectics on the binary $\mathrm{CaAl}_{2} \mathrm{Si}_{2} \mathrm{O}_{8}(\mathrm{An})-\mathrm{KAlSi}_{3} \mathrm{O}_{8}(\mathrm{Or})$ in Figure $6 \mathrm{a}$ (closed circles) are from Winkler and Ghose (1973). The equivalent minima and eutectics on the $\mathrm{H}_{2} \mathrm{O}$ and quartz saturated $\mathrm{NaAlSi}_{3} \mathrm{O}_{8}(\mathrm{Ab})-\mathrm{KAlSi}_{3} \mathrm{O}_{8}(\mathrm{Or})$ binary (closed circles) are from Tuttle and Bowen (1958) and Luth et al. (1964).

Piercing points for the five-phase equilibrium Plag, Ksp, Qtz, L, $\mathrm{H}_{2} \mathrm{O}$, investigated at $P_{\mathrm{H}_{2} \mathrm{O}}=1 \mathrm{kbar}$ by James and Hamilton (1969), are shown by open circles. Their deduced cotectic is shown by the broken line passing through these points. The smoothed cotectic curve across to the An-Or sideline is constructed to be consistent with the WinklerGhose (1973) data.

Winkler and co-workers have presented data on the fivephase equilibrium at $P_{\mathrm{H}_{2} \mathrm{O}}=5$ and $7 \mathrm{kbar}$ (see summary by Winkler 1979: 303-4). It is not known whether the unusual 


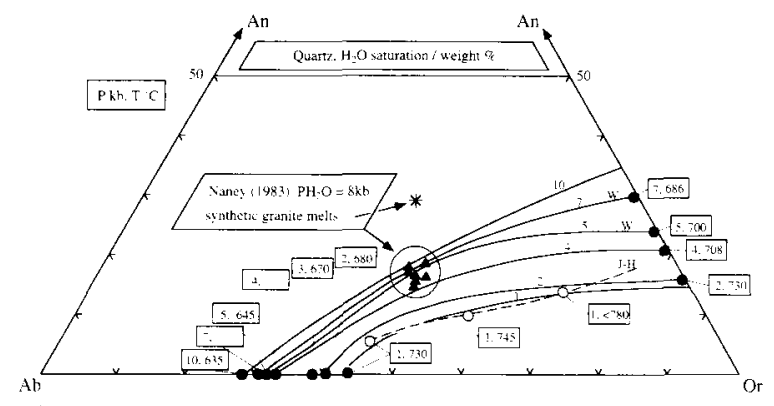

(a)

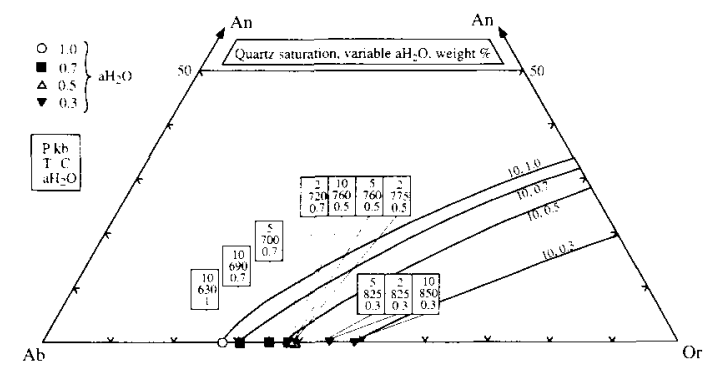

(b)

Figure 6 (a) Projection of ternary feldspar cotectics onto the plane $\mathrm{An}+\mathrm{Ab}+\mathrm{Or}$ at quartz and $\mathrm{H}_{2} \mathrm{O}$ saturation. The phase relations in $\mathrm{Ab}+\mathrm{Or}+\mathrm{Qtz}+\mathrm{H}_{2} \mathrm{O}$ are from Figures 1 and 2 (with $P$ in kbar, $T$ in C: Tuttle \& Bowen 1958; Luth et al. 1964); those for $\mathrm{An}+\mathrm{Or}+\mathrm{Qtz}+\mathrm{H}_{2} \mathrm{O}$ (closed circles) are from Winkler and Ghose (1973). The open circles (labelled 1, $T$ C) show piercing points deduced by James and Hamilton (1969) from experiments at 1 kbar. Their cotectic curve (broken line labelled $\mathbf{J}-\mathbf{H}$ ) has been smoothed to be consistent with the data of Winkler and Ghose (1973) for $\mathrm{An}+\mathrm{Or}+\mathrm{Qtz}+\mathrm{H}_{2} \mathrm{O}$. The $P_{\mathrm{H}_{2} \mathrm{O}}=5$ and $7 \mathrm{kbar}$ cotectics are taken from Winkler (1979: 303-4). It is not known whether the reported curvature around $\mathrm{An}_{5}-\mathrm{An}_{10}$ is related to ternary feldspar critical phenomena or a ternary liquid minima. The cotectics at 2, 4 and $10 \mathrm{kbar}$ are constructed from $\mathrm{Ab}+\mathrm{Or}+\mathrm{Qtz}+\mathrm{H}_{2} \mathrm{O}$ end-points. Several glass analyses (closed triangles) were reported for experiments by Naney (1983) for a synthetic granite (bulk composition indicated by asterisk) at $P_{\mathrm{H}_{2} \mathrm{O}}=8 \mathrm{kbar}$. (b) Migration of ternary feldspar cotectics at quartz saturation at $10 \mathrm{kbar}$ due to lowering $a_{\mathrm{H}_{2} \mathrm{O}}$. These are constructed with data from Ebadi and Johannes (1991) for $\mathrm{Ab}+\mathrm{Or}+\mathrm{Qtz}$ at the indicated $a_{\mathrm{H}_{2} \mathrm{O}}$ pressure ( $\mathrm{kbar}$ ) and temperature (C) and are drawn subparallel to the $10 \mathrm{kbar}$ curve for $a_{\mathrm{H}_{2} \mathrm{O}}=1$ from (a).

curvature of the projected five-phase equilibria at low An contents is an artifact of data interpretation or whether it reflects migration of the neutral point (see Abbott 1978: 250), separating cotectic crystallisation at low An content. The cotectics for 2,4 and 10 kbar are drawn simply to be consistent with the other cotectics determined experimentally. Deductions about the behaviour of the cotectics at lower $a_{\mathrm{H}_{2} \mathrm{O}}$ are based on these smoothed cotectics for $a_{\mathrm{H}_{2} \mathrm{O}}=1$.

\subsection{Five-phase cotectics at $\boldsymbol{a}_{\mathrm{H}_{2} \mathrm{O}}<1$}

To understand the compositions of initial 'granitic' melts produced by dehydration melting of mica we need to be able to locate the temperatures and compositions of the five-phase equilibria as functions of pressure and $a_{\mathrm{H}_{2} \mathrm{O}}$. However, the only data available are for the $\mathrm{Ab}+\mathrm{Or}$ sideline of the quartz- and fluid-bearing ternary feldspar space (Keppler 1989; Ebadi \& Johannes 1991). In the absence of experimental data and using $P_{\text {fluid }}=10$ kbar as an example, I have extrapolated (in Fig. 6b) the $X_{\mathrm{Or}}$ compositional and $a_{\mathrm{H}_{2} \mathrm{O}}$ data for the $\mathrm{Ab}+\mathrm{Or}+\mathrm{Qtz}$ sideline (Fig. 2) into the ternary feldspar diagram parallel to the illustrated projected cotectic for the five-phase equilibrium for $a_{\mathrm{H}_{2} \mathrm{O}}=1$ (from Fig. 6a). The errors in this extrapolation will become apparent from future experimental studies. The suggested ranges in composition, $a_{\mathrm{H}_{2} \mathrm{O}}$ and temperature for such experiments are indicated in Figure 6b. The simplest experimental strategy would be first to perform experiments on the end-member system $\mathrm{An}+\mathrm{Or}+\mathrm{Qtz}$ at various $a_{\mathrm{H}_{2} \mathrm{O}}$. It should be noted that $\mathrm{Ai}$ and Green (1989) give a projected eutectic composition of $\mathrm{Or}_{70}$ for the anhydrous $\mathrm{An}+\mathrm{Or}$ eutectic at $10 \mathrm{kbar}$, but without quartz. The present interpretation requires that the $\mathrm{An}+$ Or eutectic at quartz saturation is displaced towards $\mathrm{Or}_{85}$.

The fact that experimentally produced melts plot close to these cotectics [e.g. the results of Naney (1983) for melting of a synthetic granite at $P_{\mathrm{H}_{2} \mathrm{O}}=8 \mathrm{kbar}$ in Fig. 6a] provides some reassurance that the extrapolated isobaric five-phase cotectics are reasonably well located. However, the melts reported by Naney (1983) do contain some dissolved $\mathrm{MgO}+\mathrm{FeO}$ and some have lost quartz at high temperatures. This example illustrates well that because of the projected strong curvature of the five-phase cotectics they will not provide suitable barometers for use with modally determined proportions of feldspars from intrusive rocks.

With these provisionally located projected quartzofeldspathic cotectics at $10 \mathrm{kbar}$ for various $a_{\mathrm{H}_{2} \mathrm{O}}$, it is intended to use dehydration melting experiments on muscovite- and biotite-bearing quartzo-feldspathic rocks (pelites, gneisses, greywackes) to attempt to locate the temperatures and compositions of initial melts at various pressures and $a_{\mathrm{H}_{2} \mathrm{O}}$.

\subsection{Composition of initial melts obtained from dehydration melting experiments on mica-bearing quartzo-feldspathic rocks}

The fact that several studies have used plagioclase $\left(\mathrm{An}_{23}\right.$ to $\mathrm{An}_{30}$ ) instead of albite in dehydration melting studies of micaceous quartzo-feldspathic rocks means that it is clearly necessary to consider melting in projected ternary feldspar space and not just the projected Ab-Or binary.

Although beginning with Mica + Plag + Qtz (+ Sill), the melt composition for dehydration melting at $10 \mathrm{kbar}$ reported by Patino Douce and Johnston (1991) from temperatures of $825^{\circ} \mathrm{C}$ and above did not coexist with plagioclase (open circles in Fig. 7). Likewise the melt compositions reported in a similar study by Vielzeuf and Holloway (1988) from temperatures of $875 \mathrm{C}$ and above did not coexist with biotite (open squares in Fig. 7). The compositional trends projected backwards meet around $\mathrm{An}_{6} \mathrm{Ab}_{37} \mathrm{Or}_{57}$. This composition is close to a dehydration melt composition (triangles in Fig. 7) reported by LeBreton and Thompson (1988, analyses no. 1, $850 \mathrm{C} / 10 \mathrm{kbar}$.

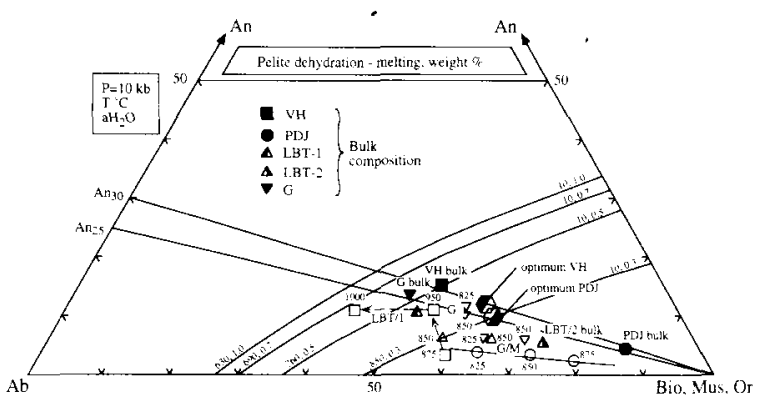

Figure 7 Results of pelitite dehydration melting experiments at $10 \mathrm{kbar}(\approx 35 \mathrm{~km}$ depth) projected onto Figure $6 \mathrm{~b}$. The glass compositions at experimental temperatures $(\mathrm{C}$ ) are indicated by open symbols: bulk compositions are indicated by closed symbols (circle, PDJPatiño Douce \& Johnston 1991: square. VH-Vielzeuf \& Holloway 1988: triangle, LBT mixtures 1 and 2-Le Breton \& Thompson 1988: inverted triangle. $G$-Gardien et al. 1994, 1995). The optimum bulk compositions for Bio + Plag + Qtz mixtures calculated by Patiño Douce and Johnston (1991: 214) shown by the half-shaded hexagons, lie between the tie lines for plagioclase $\mathrm{An}_{25}$ and $\mathrm{An}_{30}$ with biotite and quartz. The recalculation of analyses is given in Table 2. 
Table 2 Calculations of $\mathrm{An}+\mathrm{Ab}+\mathrm{Or}$ ratios from glass compositions reported from various dehydration melting studies at $10 \mathrm{kbar}$.

\begin{tabular}{|c|c|c|c|}
\hline \multirow[b]{2}{*}{ Study } & \multicolumn{3}{|c|}{ Ratio (wt \%) } \\
\hline & An & $\mathrm{Ab}$ & Or \\
\hline \multicolumn{4}{|c|}{ Patiño Douce \& Johnston (1991) } \\
\hline Plag & $26 \cdot 1$ & $73 \cdot 2$ & $0 \cdot 7$ \\
\hline Bulk & $4 \cdot 6$ & $10 \cdot 6$ & $84 \cdot 8$ \\
\hline $825 \mathrm{C}$ & $3 \cdot 6$ & $32 \cdot 6$ & $63 \cdot 8$ \\
\hline $850 \mathrm{C}$ & $2 \cdot 4$ & $26 \cdot 4$ & $71 \cdot 2$ \\
\hline $875 C$ & $1 \cdot 7$ & $19 \cdot 7$ & $78 \cdot 4$ \\
\hline \multicolumn{4}{|l|}{ Optimum protolith } \\
\hline PDJ & 8.9 & $28 \cdot 7$ & $62 \cdot 4$ \\
\hline VH & 11 & $28 \cdot 7$ & $60 \cdot 3$ \\
\hline \multicolumn{4}{|c|}{ Vielzeuf \& Holloway (1988) } \\
\hline Plag & 30 & 70 & -- \\
\hline Bulk & $15 \cdot 4$ & 32 & $32 \cdot 6$ \\
\hline $875 \%$ & $2 \cdot 6$ & $38 \cdot 8$ & $58 \cdot 6$ \\
\hline $900 \mathrm{C}$ & $10 \cdot 2$ & $36 \cdot 1$ & $53 \cdot 7$ \\
\hline $950 \mathrm{C}$ & $11 \cdot 6$ & $34 \cdot 1$ & $34 \cdot 3$ \\
\hline $1000 \mathrm{C}$ & $10 \cdot 8$ & 42 & $47 \cdot 2$ \\
\hline \multicolumn{4}{|c|}{ Le Breton \& Thompson (1988) (all at $850 \mathrm{C}$ ) } \\
\hline Bulk mix 1 & $10 \cdot 2$ & $38 \cdot 1$ & $51 \cdot 6$ \\
\hline Bulk mix 2 & $5 \cdot 2$ & $22 \cdot 5$ & $72 \cdot 3$ \\
\hline No. 1 & $6 \cdot 2$ & 37 & $56 \cdot 8$ \\
\hline No. 85 & $4 \cdot 4$ & $22 \cdot 3$ & $73 \cdot 2$ \\
\hline No. 92 & $5 \cdot 4$ & $29 \cdot 9$ & $64 \cdot 6$ \\
\hline No. 33 & $6 \cdot 5$ & $42 \cdot 4$ & $51 \cdot 07$ \\
\hline No. 54 & 12 & $51 \cdot 2$ & 37 \\
\hline \multicolumn{4}{|c|}{ Gardien et al. (1994.1995) } \\
\hline Bulk & 14 & $37 \cdot 2$ & $48 \cdot 8$ \\
\hline BPQ. $825^{\circ} \mathrm{C}$ & $11 \cdot 6$ & $30 \cdot 6$ & $37 \cdot 8$ \\
\hline BPQM. $825 \mathrm{C}$ & $5 \cdot 8$ & $30 \cdot 8$ & $63 \cdot 4$ \\
\hline BPQ. $850 \mathrm{C}$ & $10 \cdot 5$ & $31 \cdot 6$ & $37 \cdot 8$ \\
\hline BPQM, $850 \mathrm{C}$ & $5 \cdot 4$ & $25 \cdot 4$ & $69 \cdot 2$ \\
\hline
\end{tabular}

coexisting with biotite, plagioclase, $\mathrm{Al}_{2} \mathrm{SiO}_{5}$, quartz and K-feldspar). Initial melts obtained by Gardien et al. (1994. 1995) from dehydration melting experiments on $\mathrm{Bio}+\mathrm{Plag}+\mathrm{Qtz} \pm$ Musc are shown for 825 and $850 \mathrm{C}$ (inverted open triangles in Fig. 7). The data presented in Table 2 were used for constructing Figure 7 -for each set the bulk compositions are represented by the closed symbols and the melt composition by open symbols.

Although showing diversity in melt composition (not surprising considering the difficulty of obtaining electron microprobe analyses of small amounts of glass), it is reassuring that relatively small compositional regions around the projected five-phase cotectics are located. The disposition of the various bulk compositions from these studies (closed symbols in Fig. 7) indeed suggest an approach to cotectics from both the plagioclase and biotite sides.

It is also important to note that if the ratio $X_{\text {Or }}$ was taken as the single characteristic of a natural initial melt composition (as for the binary $\mathrm{Ab}-\mathrm{Or}$ system projected from quartz and $a_{\mathrm{H}_{2} \mathrm{O}}$ in Fig. 2a), it would lead to a misleading interpretation of melting temperature because in the projected ternary feldspar system cotectic the compositions clearly project far to the $X_{\mathrm{Or}}$ side of the $\mathrm{Ab}-\mathrm{Or}$ minimum.

\subsection{Eutectica or minima in ternary feldspar anatexis?}

Until now we have not been concerned with whether the division into minima or eutectica obtained in the projected binary system extends into the projected ternary feldspar system. One possibility is that the extension of the AFC into the ternary feldspar system (the composition line joining the binary $\mathrm{Ab}+\mathrm{Or}$ to the binary $\mathrm{An}+\mathrm{Or}$ critical points) coincides with a particular five-phase cotectic valley for a given pressure and $a_{\mathrm{H}, \mathrm{O}}$. In this instance the eutectic region would be located on the An-rich side and the minimum region on the Or (mica)rich side of the particular cotectic. The consequence of this is that minimum melting would apply for mica to plagioclase ratios greater than the projected ternary cotectica and that eutectic melting will occur for plagioclase to mica ratios greater than the projected ternary cotectica.

The other possibility is that the extension of the AFC into the ternary feldspar system (the composition line joining the projected binary $\mathrm{Ab}+\mathrm{Or}$ to the projected binary $\mathrm{An}+\mathrm{Or}$ critical points) lies at a higher temperature than the trace of the melt compositions along the five-phase cotectic valleys. This would mean that the projected ternary feldspar system is everywhere eutectic. Thus solidi in the five-component system (Ab, An, Or, Qtz, $\mathrm{H}_{2} \mathrm{O}$ ) at $a_{\mathrm{H}, \mathrm{O}}$ appropriate to mica dehydration melting all lie in the eutectic region within the projected ternary feldspar system.

Most bulk compositions used to experimentally determine fertility to crustal anatexis (large melt fractions generated over the smallest temperature intervals) were chosen because they contained subequal amounts of quartz and feldspar to provide the low temperature melting fraction and mica to provide $\mathrm{H}_{2} \mathrm{O}$ (we might call this 'potential fertility'). All investigated compositions project close to the five-phase cotectic valleys at the appropriate pressures and $a_{\mathrm{H}_{2} \mathrm{O}}$, with the exception of the metapelite (HQ-36) used by Patiño Douce and Johnston (1991). However, even for this mica-rich composition these workers suggest a near-eutectic melting behaviour (A. Patiño Douce 1995, pers. comm.).

There are distinct advantages to the interpretation of fertility to crustal anatexis by assuming that Mica + Plag + Qtz melting is always eutectic. Thus the observed variation in the amount of melt as a function of temperature would be related to the chemistry of coexisting phases more than their modal amounts.

\section{7. $a \mathrm{H}_{2} \mathrm{O}$ for common rocks and optimum mineral proportions for fertility}

Although not experimentally investigated in detail, it was suggested by Burnham (1979) that initial muscovite dehydration melting corresponds to an $X_{\mathrm{w}}^{\mathrm{m}}$ of about 0.6 and initial biotite dehydration melting to an $X_{\mathrm{w}}^{\mathrm{m}}$ of about $0 \cdot 35$. These values were supported by calculations by Thompson (1988) and LeBreton and Thompson (1988), who suggested that biotite dehydration melting can begin around $790 \mathrm{C}$ where $X_{\mathrm{w}}^{\mathrm{m}}$ is between 0.5 and 0.45 . Whatever the true value of $X_{\mathrm{w}}^{\mathrm{m}}$ for a particular dehydration melting reaction, this quantity will not vary much during a particular anatectic episode in the absence of a fluid phase. It is useful to examine the deduced initial melt compositions and the projected five-phase equilibria at these suggested values for $X_{w}^{\mathrm{m}}$.

The cotectics illustrated in Figure 8 for 5,10 and $20 \mathrm{kbar}$ pressure at $X_{\mathrm{w}}^{\mathrm{m}}=0.6$ and 0.35 were obtained in a similar way to that discussed for Figure $6 \mathrm{~b}$. The cotectics show the lowest temperature melts at quartz saturation and are related to the rock compositions for optimum fertility by tie lines to the equilibrium feldspar compositions. These plagioclase and alkali feldspar compositions generate ternary melts that lie at lower temperature, smaller $X_{\mathrm{An}}, X_{\mathrm{Or}}$, but larger $X_{\mathrm{Ab}}$, down the appropriate cotectics. The projected $\mathrm{An}+\mathrm{Ab}+\mathrm{Or}$ diagram is a useful tool with which to deduce rock fertility because both muscovite and biotite have very high $\mathrm{K} / \mathrm{Na}$ ratios and plot virtually at $\mathrm{KAlSi}_{3} \mathrm{O}_{8}$. For plagioclase, the weight per cent and mole per cent are very close and Or components have been ignored. 


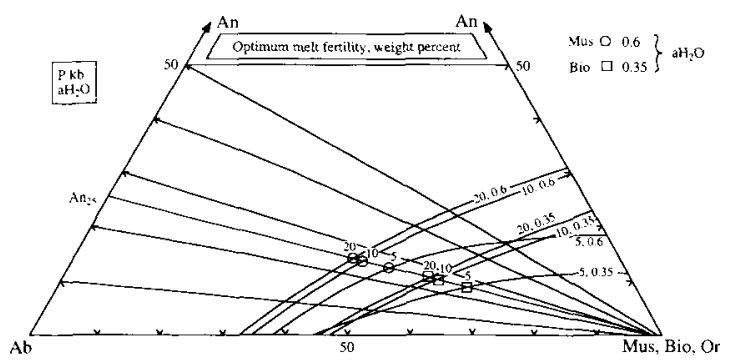

Figure 8 Predicted compositions of optimum fertility for mixtures of muscovite or biotite with plagioclase of indicated composition at various pressures and $a_{\mathrm{H}_{2} \mathrm{O}}$. An example for $\mathrm{An}_{25}$ is shown by open circles (muscovite) and open squares (biotite). The projected cotectics onto $\mathrm{An}+\mathrm{Ab}+\mathrm{Or}$ at quartz saturation are shown for $P=5,10$, $20 \mathrm{kbar}$, at $a_{\mathrm{H}_{2} \mathrm{O}}=0.6$ and 0.35 (Figures 5 and $6 \mathrm{~b}$ )

\subsection{Effect of plagioclase composition and proportion on optimum melt fertility}

As can be seen in Figure 8, because of the high angles between the projected ternary cotectics and the mica-plagioclase tie lines, very different proportions of plagioclase and mica are required for optimum fertility depending on the plagioclase composition. For albite-rich plagioclase the optimum proportion of plagioclase is greater than that of mica. For anorthite-rich plagioclase (e.g. $\mathrm{An}_{50}$ ) the optimum proportion of mica is greater than that of feldspar.

For a particular plagioclase composition (e.g. $\mathrm{An}_{25}$ in Fig. 8) it can be seen that the optimum fertility composition migrates with increasing pressure towards greater amounts of feldspar. It is also seen that biotite rocks (open squares) require more mica relative to feldspar than muscovite rocks (open circles) or. conversely, muscovite dehydration melts are more sodic than biotite dehydration melts. This is a reflection of the value of $X_{\mathrm{w}}^{\mathrm{m}}$ at the different temperatures of dehydration melting of the two micas.

It is of great interest to compare the optimum fertility compositions deduced here with those calculated by Patiño Douce and Johnston (1991: 214). Their optimum compositions were obtained by comparing their values and Vielzeuf and Holloway's (1988) experimentally determined melt compositions in the projection $\mathrm{Na}_{2} \mathrm{O} \cdot \mathrm{Al}_{2} \mathrm{O}_{3}-\mathrm{K}_{2} \mathrm{O} \cdot \mathrm{Al}_{2} \mathrm{O}_{3}-(\mathrm{MgO}+\mathrm{FeO})$. Patiño Douce and Johnston's optimum protoliths for melt fertility were obtained by mass balance calculations and have the following modes (in wt \%)

\section{Patiño Douce and Johnston}

$41 \%$ Bio, 23\% Plag, 31\% Qtz, $6 \% \mathrm{Al}_{2} \mathrm{SiO}_{5}$

Vielzeuf and Holloway:

36\% Bio, 21\% Plag, 34\% Qtz, 9\% $\mathrm{Al}_{2} \mathrm{SiO}_{5}$

It is important, as these workers noted, that the optimum protolith is closer to a metagreywacke than a pelitic schist. These optimum protolith compositions are shown by the halfclosed hexagons in Figure 7. It can be seen that these compositions compare remarkably well with those deduced here (Fig. 8), using different reasoning.

\subsection{Effect of pressure on the relative fertilities of psammites (granites, greywackes and gneisses) compared with metapelites}

A further implication of the results of Figure 8 is that pelites are more fertile than psammites at low pressures (e.g. $5 \mathrm{kbar}$ ) and when the plagioclase is anorthite-rich (c.g. $\mathrm{An}_{40}-\mathrm{An}_{50}$ ). Psammites are more fertile than pelites at higher pressures (e.g. 10-20 kbar) and with more albitic plagioclase. For a typical pelite (e.g. with $\mathrm{An}_{25}$ in Fig. 8) the cotectic with muscovite lies at higher $a_{\mathrm{H}_{2} \mathrm{O}}(\approx 0.6)$ and $X_{\mathrm{Ab}}(\approx 0.42)$ than with biotite $\left(a_{\mathrm{H}_{2} \mathrm{O}} \approx 0.35 ; X_{\mathrm{Ab}} \approx 0.32\right)$, thus dehydration melting of muscovite requires $10 \%$ more plagioclase for fertility than biotite.

With increasing pressure, to at least $30 \mathrm{kbar}$, granite minimum and mica dehydration melts become more sodic. The first melts from Mus + Plag + Qtz melting are more sodic than, and form by dehydration melting before (at lower temperatures than), the first melts from Bio + Plag + Qtz. This indicates that the $a_{\mathrm{H}_{2} \mathrm{O}}$ of these melts is greater than 0.3 (Figs 1,8 ). This simple deduction is of great help when evaluating $a_{\mathrm{H}_{2} \mathrm{O}}$ during the dehydration melting of biotite.

\section{Further refinements on fertility}

Some very simple and necessary observations and experiments will enable great refinements to our understanding of the controls of rock fertility. For example, no attempt has been made here to include plagioclase immiscibility gaps, the cases arising from a possible ternary feldspar minimum or the occurrence of $\mathrm{H}_{2} \mathrm{O}$-bearing residual minerals (e.g. cordierite, Stevens et al. 1995). Additional investigations of the compositions and stability of the ternary feldspar minimum, at high pressure and at quartz saturation, are clearly desirable.

\subsection{Ternary minimum melting}

A quartz-saturated ternary feldspar cotectic melt could form if some ternary composition had a solidus temperature lower than minimum/eutectic melting on the $\mathrm{Ab}+\mathrm{Or}+\mathrm{Qtz}$ sideline (see, for example, Stewart \& Roseboom 1962; Carmichael 1963; Abbott 1978). The existence of such a quartz-saturated ternary feldspar cotectic melt would mean that a wide range of bulk compositions would produce the same initial melt composition. For such a case it would be far from easy to distinguish melt evolution at low melt fractions in different lithologies and many difficult to perform experiments would be needed. Until there is a reason to think otherwise, it is certainly more practical to consider projected ternary feldspar liquids to be always less anorthitic than plagioclase.

\subsection{Curvature along the cotectic valleys}

In the present figures the cotectic valleys have been drawn without inflections and with very little curvature. This means that the tangents at specific compositions along the cotectic are not changing. For the present example then it is sufficient to define optimum fertility by the intersection of a particular tie line with a specific cotectic.

It is suspected, however, that as the five-phase cotectic at 1 kbar $P_{\mathrm{H}_{2} \mathrm{O}}$ approaches the $\mathrm{Ab}+\mathrm{Or}\left(+\mathrm{Qtz}+\mathrm{H}_{2} \mathrm{O}\right)$ sideline it changes from even to odd through a reaction relationship (i.e. becomes peritectic; see James \& Hamilton 1969). Abbott (1978) noted that the curvature may be enough for low An melts to cause $\mathrm{K}$-feldspar to move from an even (cotectic) to odd (peritectic) relationship with the melt. In the present example it has been assumed that all melts are cotectic for minimum) between mica and plagioclase so that any peritectic reactions that are relevant must involve K-feldspar in addition.

\section{3. $P-T-X$ along the cotectic valleys}

The present interpretation (Fig. 6a) suggests that the $\mathrm{An}+\mathrm{Or}+\mathrm{Qtz}$ cotectic temperature is about $50 \mathrm{C}$ higher than the $\mathrm{Ab}+\mathrm{Or}+\mathrm{Qtz}$ cotectic for a given pressure and $a_{\mathrm{H}_{2} \mathrm{O}}$. Such small temperature differences along the cotectics mean that the details of continuous reactions would be smeared out in natural migmatites.

Tuttle and Bowen (1958: 136) have shown the strong concentration of granitic rock analyses in the low An region of $\mathrm{An}+\mathrm{Ab}+$ Or. The analyses include pyroclastic volcanic 
rocks which have equilibrated at low pressure. Such rocks are frequently rich in $\mathrm{MgO}+\mathrm{FeO}$ and contain biotite, especially when metamorphosed. It is suggested in Figure 8 that the 'biotite' cotectics with plagioclase and quartz do not vary in composition with temperature and pressure from 5 to $20 \mathrm{kbar}$ (this is equivalent to saying that $\mathrm{d} P / \mathrm{d} T$ for the biotite melting reaction is nearly infinite-vertical in a $P-T$ diagram such as Fig. 4). Thus low pressure pyroclastic volcanic rocks are potentially fertile compositions in terms of $\mathrm{An}+\mathrm{Ab}+\mathrm{Or}$ for anatexis at any pressure in the lower crust. However, volcanic rocks contain only small amounts of micas and like 'granites and granodiorites are therefore too anhydrous to be fertile protoliths for granitoid magmas' (Patiño Douce \& Johnston 1991: 214).

\subsection{Superimposed mode composition diagrams on cotectic valleys}

The position of a cotectic valley is determined by near-eutectic phase relations between plagioclase and $\mathrm{K}$-feldspar (or mica proxy) at quartz saturation. Thus at a given pressure and $a_{\mathrm{H}_{2} \mathrm{O}}$, solidus temperature and composition are not dependent on the proportions of phases, whereas the width of the melting interval is. The depth of the cotectic valley (width of the melting interval) is determined mainly by the $X_{\mathrm{w}}^{\mathrm{m}}$ and the proportion of plagioclase to mica.

The degree of rock fertility depends on the melting reaction temperature of particular mica and plagioclase compositions with quartz. The situation may be visualised with an analogy of erecting a cable across a valley - the feldspar-quartz phase relations describe the valley, the mica compositions locate the cable and the temperature is given by the height. For suitably Fe-enriched mica compositions lower temperature melting reactions can occur near the bottom of the valley. A more Mg-enriched biotite will only react with plagioclase at higher temperatures - near to the top of the valley (e.g. LeBreton et al. 1995; Singh 1995). Continuous reaction paths involving $\mathrm{Fe}, \mathrm{Mg}, \mathrm{Ti}$ and $\mathrm{F}$ in biotite and $X_{\mathrm{An}}$ in plagioclase will take complex routes up and across the simple cotectic valleys. Another major experimental problem is to work out the systematics of anatexis in such chemically varied cotectic valleys.

\section{Concluding remarks}

A large amount of experimental data has been examined to obtain bounds on the optimum fertility to melt production of crustal rocks. It can be concluded that the most fertile assemblages, defined by specific modal amounts of common minerals, vary significantly with increasing pressure and decreasing $a_{\mathrm{H}_{2} \mathrm{O}}$ (a conclusion also reached by Patiño-Douce, this issue). Even though great extrapolations of experimental results have been made, the conclusions reached in this paper are considered to be valid.

It is recognised that many of the extrapolations herein are made well outside any controlling experimental data. For each example the extrapolations can be used to greatly limit the ranges of rock composition, $a_{\mathrm{H}_{2} \mathrm{O}}^{\text {fluid }}, T$ and $P$ that need to be considered for future experiments. These results are being used to improve existing models for optimum melt production (e.g. Clemens \& Vielzeuf 1987) across the whole spectrum of common metasedimentary and magmatic quartzo-feldspathic rock compositions.

\section{Acknowledgements}

It is a great pleasure to acknowledge discussions on rock fertility over the years with John Clemens, Véronique Gardien,
Nicole LeBreton, Bob Tracy, Peter Ulmer. Daniel Vielzeuf and Steve Wickham. I thank Dave Hamilton for communication about his work with Dick James. The manuscript was carefully reviewed by Rick Abbott, Alberto Patiño Douce and Jim Beard. I also thank Mike Brown for very useful comments. Ursula Stidwill and Claudia Büchel typed the manuscript and Guy Simpson drafted the final figures. The Schweizerische National Fonds is gratefully acknowledged for financial support.

\section{References}

Abbott. R. N. 1978. Peritectic reactions in the system. An-Ab-Or-Qz- $\mathrm{H}_{2} \mathrm{O}$. CAN MINERAL 16, 245-56.

Ai. Y. \& Green, D. H. 1989. Phase relations in the system anorthitepotassium-feldspar at $10 \mathrm{kbar}$ with emphasis on their solid solutions. MINERAL MAG 53, 337-45.

Burnham, C. W. 1967. Hydrothermal fluids at the magmatic stage. In: Barnes, H. L. (ed.) Geochemistry of hydrothermal ore deposits. 34-67. New York: Holt, Rinehart and Winston.

Burnham, C. W. 1979. Magmas and hydrothermal fluids. In: Barnes. H. L. (ed.) Geochemistry of hydrothermal ore deposits. 2nd edn. 71-136. New York: Wiley-Interscience.

Carmichael, I. S. E. 1963. The crystallization of feldspar in volcanic acid liquids. Q J GEOL SOC LONDON 119, 95-131.

Clemens, J. D. \& Vielzeuf, D. 1987. Constraints on melting and magma production in the crust. EARTH PLANET SCI LETT 86, 287-306.

Ebadi, A. \& Johannes. W. 1991. Beginning of melting and composition of first melts in the system $\mathrm{Q} z-\mathrm{Ab}-\mathrm{Or}-\mathrm{H}_{2} \mathrm{O}-\mathrm{CO}_{2}$. CONTRIB MINERAL PETROL 106, 286-95.

Gardien, V., Thompson, A. B., Grujic, D. \& Ulmer, P. 1994. The role of the source composition on melt fractions generation during crustal anatexis. EOS, TRANS AM GEOPHYS UNION. 75, $359-60$.

Gardien, V., Thompson, A. B., Grujic, D. \& Ulmer, P. 1995. Melt fractions during crustal anatexis. Experimental melting of biotite + plagioclase + quartz \pm muscovite assemblages and implications for crustal melting. J GEOPHYS RES 100, 15581-91.

Harris, N. B. W. \& Inger, S. 1992. Trace element modelling of pelitederived granites. CONTRIB MINERAL PETROL 110, 46-56.

Holtz, F. \& Johannes, W. 1991. Experimental investigation of $\mathrm{H}_{2} \mathrm{O}-$ saturated and $\mathrm{H}_{2} \mathrm{O}$-undersaturated liquidus phase relations in the system $\mathrm{NaAlSi}_{3} \mathrm{O}_{8}-\mathrm{KAISi}_{3} \mathrm{O}_{8}-\mathrm{SiO}_{2}-\mathrm{H}_{2} \mathrm{O}-\mathrm{CO}_{2}$ at 2 and $5 \mathrm{kbar}$. J PETROL 32, 935-58.

Huang, W. L. \& Wyllie, P. J. 1975. Melting reactions in the system $\mathrm{NaAISi} \mathrm{O}_{8}-\mathrm{KAISi}_{3} \mathrm{O}_{8}-\mathrm{SiO}_{2}$ to 35 kilobars, dry and with excess water. J GEOL 83, 737-48.

Huang, W. L. \& Wyllie, P. J. 1981. Phase relationship of S-type granite with $\mathrm{H}_{2} \mathrm{O}$ to $35 \mathrm{kbar}$ : Muscov granite from Harney Peak, South Dakota. J GEOPHYS RES 86, 1015-29.

James, R. S. \& Hamilton, D. L. 1969. Phase relations in the system $\mathrm{NaAlSi}_{3} \mathrm{O}_{8}-\mathrm{KAlSi}_{3} \mathrm{O}_{8}-\mathrm{CaAl}_{2} \mathrm{Si}_{2} \mathrm{O}_{8}-\mathrm{SiO}_{2}$ at 1 kilobar water vapour pressure. CONTRIB MINERAL PETROL 21, 111-41.

Keppler, H. 1989. The influence of the fluid phase composition on the solidus temperatures in the haplogranite system. $\mathrm{NaAISi} \mathrm{O}_{8}-\mathrm{KAISi}_{3} \mathrm{O}_{8}-\mathrm{SiO}_{2}-\mathrm{H}_{2} \mathrm{O}-\mathrm{CO}_{2}$. CONTRIB MINERAL PETROL 102, 321-7.

Le Breton, N. \& Thompson, A. B. 1988. Fluid-absent (dehydration) melting of biotite in metapelites in the early stage of crustal anatexis. CONTRIB MINERAL PETROL 99, 226-37.

Le Breton, N., Scaillet, B. \& Pons, J. 1995. Amphibole stability in granitoid melts. Experimental constraints. TERRA ABSTR 7, 297.

Luth, W. C. 1969. The systems $\mathrm{NaAlSi}_{3} \mathrm{O}_{8}-\mathrm{SiO}_{2}$ and $\mathrm{KAISi}_{3} \mathrm{O}_{8}-\mathrm{SiO}_{2}$ to $20 \mathrm{kbar}$ and the relationship between $\mathrm{H}_{2} \mathrm{O}$ content, $\mathrm{P}_{\mathrm{H} 2 \mathrm{O}}$, and $\mathbf{P}_{\text {total }}$ in granitic magmas. AM J SCI 267-A, 325-41.

Luth, W. C., Jahns, R. H. \& Tuttle, O. F. 1964. The granite system at pressures of 4 to 10 kilobars. J GEOPHYS RES 69, 759-73.

Naney, M. T. 1983. Phase equilibria of rock forming ferromagnesian silicates in granitic systems. AM J SCI 283, 993-1033.

Patiño Douce A. E. 1996. Effects of pressure and $\mathrm{H}_{2} \mathrm{O}$ content on the compositions of primary crustal melts. TRANS R SOC EDINBURGH 87, 000-000.

Patiño Douce, A. E. \& Beard, J. S. 1995. Dehydration-melting of biotite gneiss and quartz amphibolite from 3 to $15 \mathrm{kbar}$. J PETROL 36, 707-38.

Patiño Douce, A. E. \& Johnston, A. D. 1991. Phase equilibria and melt productivity in the pelitic system: implications for the origin 
of peraluminous granitoids and aluminous granulites. CONTRIB MINERAL PETROL 107, 202-18.

Petö. P. 1976. An experimental investigation of melting relations involving muscovite and paragonite in the silica-saturated portion of the system $\mathrm{K}_{2} \mathrm{O}-\mathrm{Na}_{2} \mathrm{O}-\mathrm{SiO}_{2}-\mathrm{H}_{2} \mathrm{O}$ to $15 \mathrm{kbar}$ total pressure PROGR EXP PETROL NERC LONDON 3, 41-5.

Petö. P. \& Thompson. A. B. 1974. Wet and dry melting of white micaalkali feldspar assemblages. TRANS AM GEOPHYS UNION 55, 479 .

Schairer, J. F. 1950. The alkali-feldspar join in the system $\mathrm{NaAlSi}_{3} \mathrm{O}_{8}-\mathrm{KAISi}_{3} \mathrm{O}_{8}-\mathrm{SiO}_{2}$. J GEOL 58, 512-8.

Singh. J. 1995. Dehydration melting of tonalites-implications for the origin of continental crust. TERRA ABSTR 7, 297.

Skjerlie, K. P. \& Johnston, A. D. 1992. Vapor-absent melting at $10 \mathrm{kbar}$ of biotite- and amphibole-bearing tonalitic gneiss: implications for the generation of A-type granites. GEOLOGY $20,263-6$

Skjerlie, K. P. \& Johnston, A. D. 1993. Fluid-absent melting behaviour of an F-rich tonalitic gneiss at mid-crustal pressures: implications for the generation of anorogenic granites. J PETROL 34, 785-815.

Stevens, G.. Clemens. J. D. \& Droop. G. T. R. 1995. Hydrous cordierite in granulites and crustal magma production. GEOLOGY 23, 925-8

Stewart. D. B. \& Roseboom. E. H. 1962. Lower temperature terminations of the three-phase region plagioclase-alkali feldsparliquid. J PETROL 3, 280-315.

Thompson. A. B. 1982. Dehydration melting of pelitic rocks and the generation of $\mathrm{H}_{2} \mathrm{O}$-undersaturated granitic liquids. AM J SCl 282, $1567-95$.
Thompson, A. B. 1988. Dehydration melting of crustal rocks. REND SOC ITAL MINERAL PETROL 43, 41-60.

Thompson, A. B. \& Connolly, J. A. D. 1995. Melting of the continental crust: some thermal and petrological constraints on anatexis in continental collision zones and other tectonic settings. J GEOPHYS RES 100, 15565-79.

Thompson, A. B. \& Tracy, R. J. 1979. Model systems for anatexis of pelitic rocks. CONTRIB MINERAL PETROL 70, 429-38.

Thompson, J. B. \& Thompson, A. B. 1976. A model system for mineral facies in pelitic schists. CONTRIB MINERAL PETROL 58, $243-77$.

Tuttle. O. F. \& Bowen, N. L. 1958, Origin of granite in the light of experimental studies in the system $\mathrm{NaAlSi}_{3} \mathrm{O}_{8}-\mathrm{KAISi}_{3} \mathrm{O}_{8}-\mathrm{SiO}_{2}-$ $\mathrm{H}_{2} \mathrm{O}$. GEOL SOC AM MEM 74, $153 \mathrm{pp}$.

Vielzeuf, D. \& Holloway, K. R. 1988. Experimental determination of the fluid-absent melting relations the pelitic system. Consequences for crustal differentiation. CONTRIB MINERAL PETROL 9, $257-76$.

Vielzeuf, D. \& Montel, J. M. 1994. Partial melting of metagrey wackes. Part I. Fluid-absent experiments and phase relationships. CONTRIB MINERAL PETROL 117, 375-93.

Waldbaum, D. R. \& Thompson, J. B. 1969. Mixing properties of sanidine crystalline solutions: IV. Phase diagrams from equation of state. AM MINERAL 54, 1274-98.

Winkler, H. G. F. 1979. Anatexis, formation of migmatites, and origin of granitic magmas. In Petrogenesis of metamorphic rocks, 5th edn. New York: Springer.

Winkler. H. G. F. \& Ghose, N. C. 1973. Further data on the eutectics in the system $\mathrm{Qz}-\mathrm{Or}-\mathrm{An}-\mathrm{H}_{2} \mathrm{O}$. $\mathrm{N}$ JAHRB MINERAL MONATSH 31, $481 \cdots 4$.

ALAN BRUCE THOMPSON. Erdwissenschaften. ETH Zurich, CH-8092, Switzerland. 